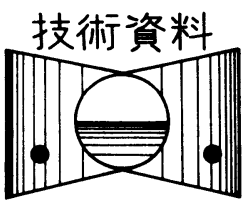

\title{
UEC52L 形舶用ディーゼル機関の開発*
}

\author{
平山義則 ${ }^{* *}$. 関岡信明 ${ }^{* *}$
}

\author{
Development of the UEC52L Type Marine Diesel Engine
}

By Yoshinori Hirayama, Nobuaki Sekioka

Mitsubishi Heavy Industries Ltd., which has been developing and manufacturing many UEC type diesel engines since 1955, completed and delivered the first 6UEC52L type engine, one of the newest L series on February 1984 as scheduled.

The $\mathrm{L}$ series of UEC diesel engines, based on the good experiences obtained with more than $300 \mathrm{H}$ and $\mathrm{HA}$ type engines, has been developed and designed based on the philosophy of meeting the needs of customers, i.e., energy saving, lowest propeller revolution, high reliability and easy maintenance.

The $\mathrm{L}$ type engine has been designed so as to have the merits for each shipowners, crews and shipyards respectively.

This paper describes the concepts used in developing the $L$ type engine, its main features and the test results of the first 6UEC52L engine. From the test results the UEC $L$ type engine has been proved to have the best specific fuel consumption, as low as the designed value, and the same reliability as conventional type engines as confirmed from various measurements.

\section{1.はじめに}

当社では, 独自の技術開発による三菱UE 形機関を舶 用主機として, 昭和 30 年以来供給し続けている. このた び, その最新シリーズであるUEC-L 形機関の初号機 6 UEC 52 L 形機関を完成した.

低燃費・ロングストローク機関として, 昭和 54 年に UEC-H形を開発, 更に昭和 57 年には, 出力を約 $10 \%$ 增大させ，燃費を 5 6 g/ps. h改善したHA形を開発し た.これらは時代のニーズに合致したものとして, 海 運界に好評裡に迎えられた。昭和 58 年までの生産台数 は, H形が 253 台, HA形が 134 台となっており, 昭和 58 年の国内主機生産実績台数の首位を占めている.

これら実績を踏まえて, このたび更に出力を $5 \%$ 増大 し, 燃費を $4 \mathrm{~g} / \mathrm{ps} \cdot \mathrm{h}$ 低減した超ロングストローク・低 回転のUEC-L形機関を開発した.

図 1 に, 本機関の開発経緯と特長を示す. 本機関は, 船主・乗組員・造船所各々にメリットがあるよう特に配 慮して開発した機関である。

*原稿受付 昭和 59 年 5 月 10 日

**正会員 三菱重工業(株)（横浜市金沢区幸浦 1-8-1）

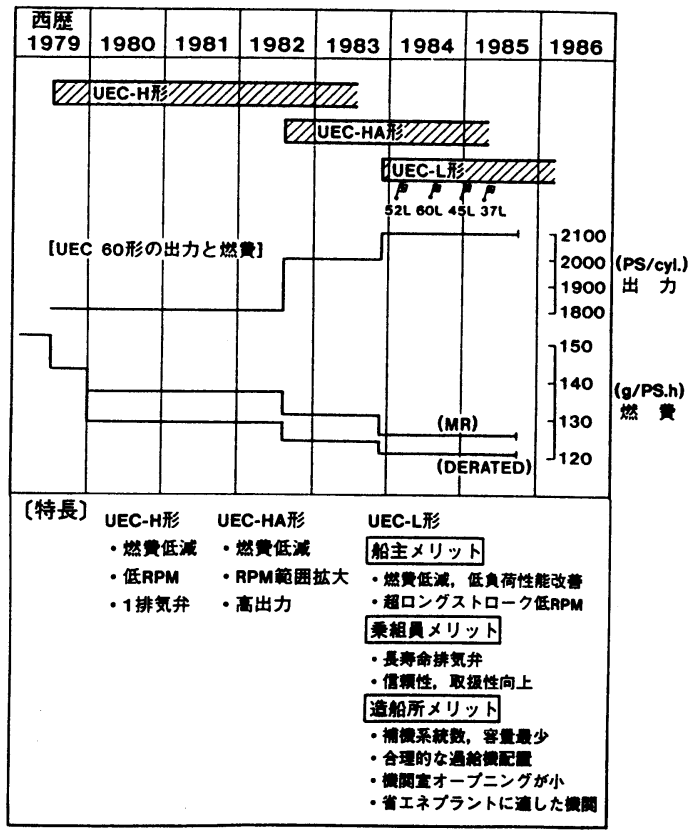

図 1 UEC-L形機関の開発経緯と特長 


\section{2. 主要諸元}

L形の主要諸元決定に際しては, 船舶の動向と主機出 力・回転数の適合性に留意し, 最適のストローク/ボア 比を選定した.

図 2 に,乙れまで生産された H形とHA形の定格点を 集計して示す. 併せて, 今後 10 年間位に要求される主 機出力と回転数の関係の将来予測例を示す.

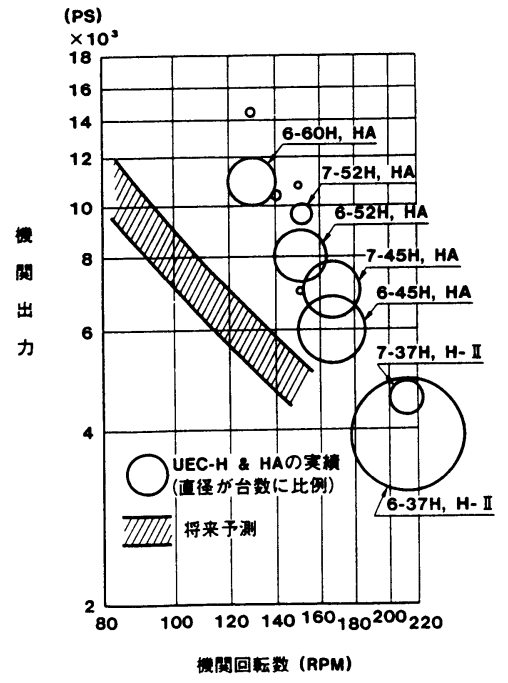

図 2 機関出力一回転数の現状と将来予測

図 3 K，L形の出力と回転数範囲を示す. 図 2 と 3 を 比べるとわかるように，L形機関は，H形などを搭載し た従来形の船舶にあ適合すると共に，今後の新しい低回 転仕様の船舶にも広く対応できる出力仕様としている。

表 1 亿，L形シリーズの主要目を示す． $60 \mathrm{~L} ， 52 \mathrm{~L}$ ， 45L形のストローク/ボア比は, 3.17〜3.0 の超ロングス トロークとし，回転数を低減させている，しかし， 37 L形は回転数よりむしろ総合経済性を考えて, 従来の $\mathrm{H}$, HA 形と同一のストローク, 回転数としている.

H形以降の燃費低減の経緯とその手法を図 4 亿示す。 燃費は過去 5 年間に, 静圧過給化, 燃料噴射系改善, 最 高圧力の上昇, 過給機効率の向上, 掃気効率の改善, 口 ングストローク化等により，約 $25 \mathrm{~g} / \mathrm{ps} \cdot \mathrm{h}$ 低減してきた。

L 形の燃費は, 掃気効率の改善・最高圧力の上昇・口 ングストローク化・掃排気タイミング遅延による有効ス トローク增大等の手段で達成している。

図 5 K, $52 \mathrm{HA}$ 形と $52 \mathrm{~L}$ 形の断面図, 主要寸法, 重 量の比較を示す.ピストンストロークは，L形の方が 350 $\mathrm{mm}$ 長いにもかかわらず, 小連掉比等の採用により, 機 関全高は $500 \mathrm{~mm}$, ピストン引抜高さは $360 \mathrm{~mm}$ の増加に とどまっている，機関全長は，クランク軸径を増大して シリンタ中心距離を縮め,さらにスラストカラー部配置 の土夫により, 逆に $810 \mathrm{~mm}$ 短縮している.

Journal of the M.E.S.J., Vol.19, No.11

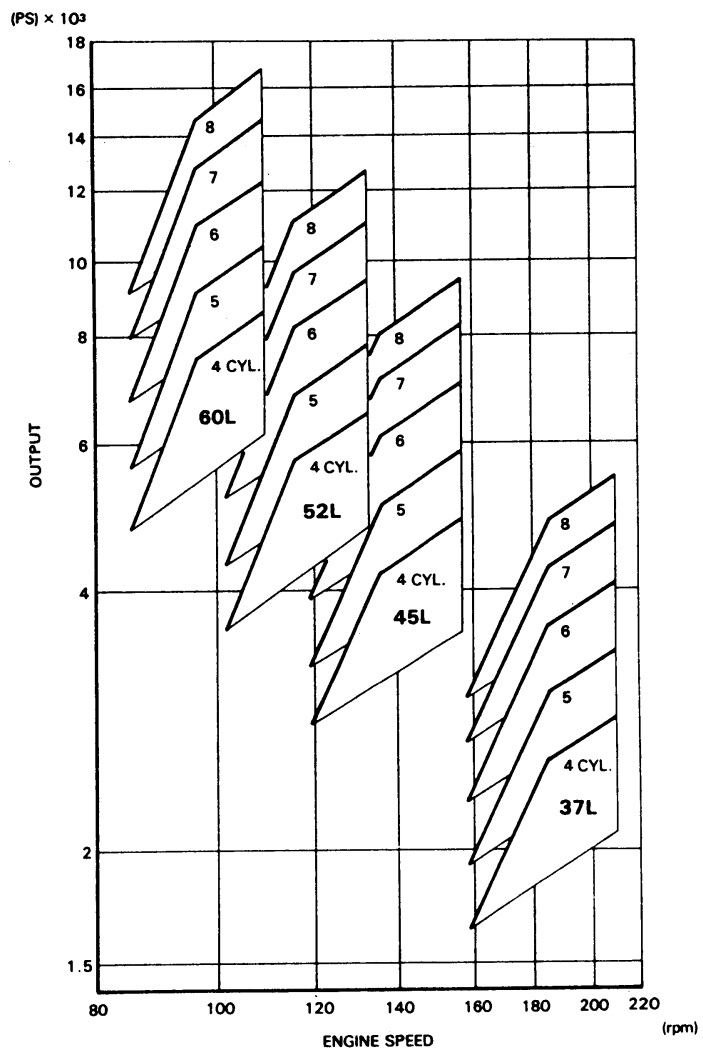

図 3 UEC-L形機関出力 ・ 回転数範囲

表 1 UEC-L形機関主要目

\begin{tabular}{|c|c|c|c|c|c|}
\hline \multicolumn{2}{|l|}{ 形式 } & UEC37L & UEC45L & UEC52L & UEC6OL \\
\hline \multicolumn{2}{|l|}{ シリンダ数 } & $4 \sim 8$ & $4 \sim 8$ & $4 \sim 8$ & $4 \sim 8$ \\
\hline シリンダ径 & $\mathrm{mm}$ & 370 & 450 & 520 & 600 \\
\hline $\begin{array}{c}\text { ビストン } \\
\text { ストローク } \\
(S / D)\end{array}$ & $\mathrm{mm}$ & $\begin{array}{c}880 \\
(2.38)\end{array}$ & $\begin{array}{l}1,350 \\
(3.00)\end{array}$ & $\begin{array}{l}1,600 \\
(3.08)\end{array}$ & $\begin{array}{c}1,900 \\
(3.17)\end{array}$ \\
\hline シリンダ当り出カ & PS/cyl & 700 & 1,200 & 1,600 & 2,100 \\
\hline 回転数 & $\begin{array}{l}\text { Rev/ } \\
\text { min }\end{array}$ & 210 & 158 & 133 & 110 \\
\hline 正味平均有効压力 & $\begin{array}{l}\mathrm{kg} / \mathrm{cm}^{\prime} \\
\text { (bar) }\end{array}$ & $\begin{array}{c}15.85 \\
(15.54)\end{array}$ & $\begin{array}{c}15.92 \\
(15.61)\end{array}$ & $\begin{array}{c}15.93 \\
(15.62)\end{array}$ & $\begin{array}{c}15.99 \\
(15.68)\end{array}$ \\
\hline 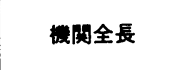 & $\mathrm{mm}$ & $\begin{array}{r}4,650- \\
7,535\end{array}$ & $\begin{array}{r}4,650- \\
7,930\end{array}$ & $\begin{array}{r}5,350- \\
9,190\end{array}$ & $\begin{array}{r}6,100- \\
10,540\end{array}$ \\
\hline 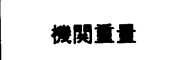 & ton & $54-97$ & 111 - & $\begin{array}{r}171- \\
308\end{array}$ & $\begin{array}{r}265- \\
476\end{array}$ \\
\hline $\begin{array}{l}\text { ピストン } \\
\text { 引抜き高さ }\end{array}$ & $\mathrm{mm}$ & 4,770 & 6,600 & 7,700 & 9,030 \\
\hline 台板幅 & $\mathrm{mm}$ & 1,900 & 2,540 & 3,000 & 3,450 \\
\hline 㜣料消费率 & $\begin{array}{l}g / P S \cdot h \\
(g / k w h)\end{array}$ & $\begin{array}{c}132 \\
(179)\end{array}$ & $\begin{array}{c}130 \\
(177)\end{array}$ & $\begin{array}{c}128 \\
(174)\end{array}$ & $\begin{array}{c}127 \\
(173)\end{array}$ \\
\hline
\end{tabular}

November, 1984 


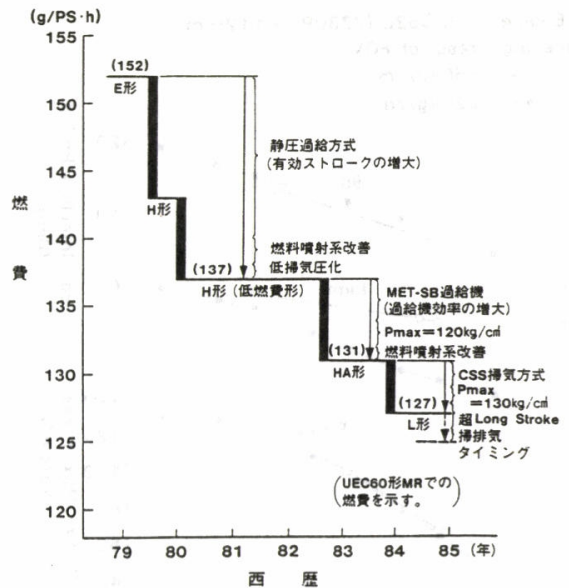

図 4 燃費低減とその手法

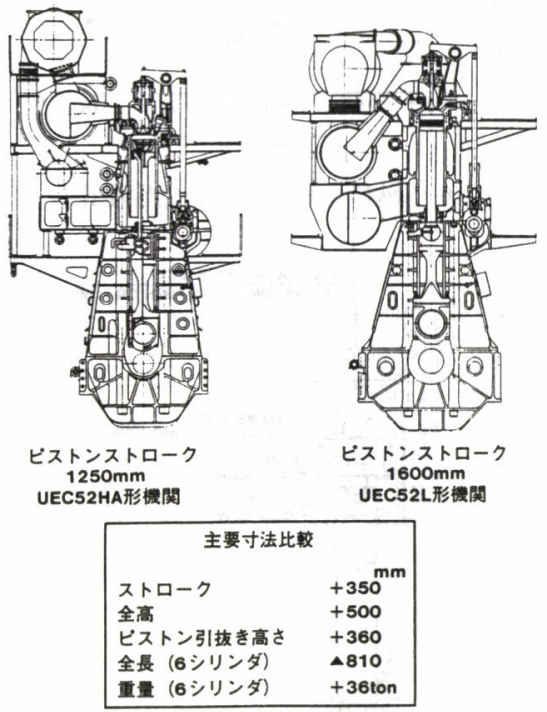

図 5 UEC-HA及びL形機関断面比較
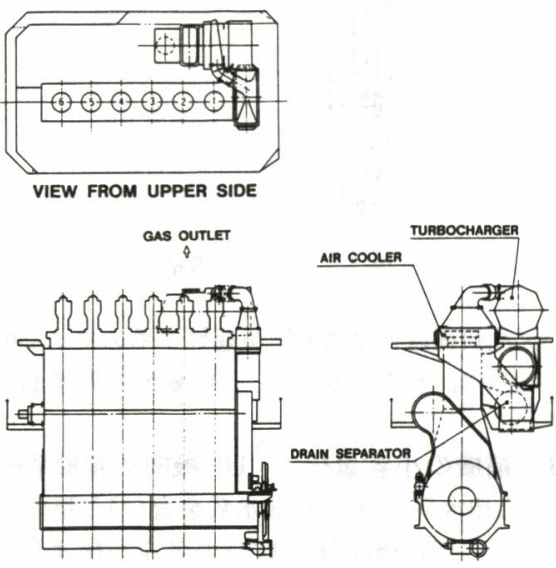

VIEW FROM CAMSHAFT SIDE

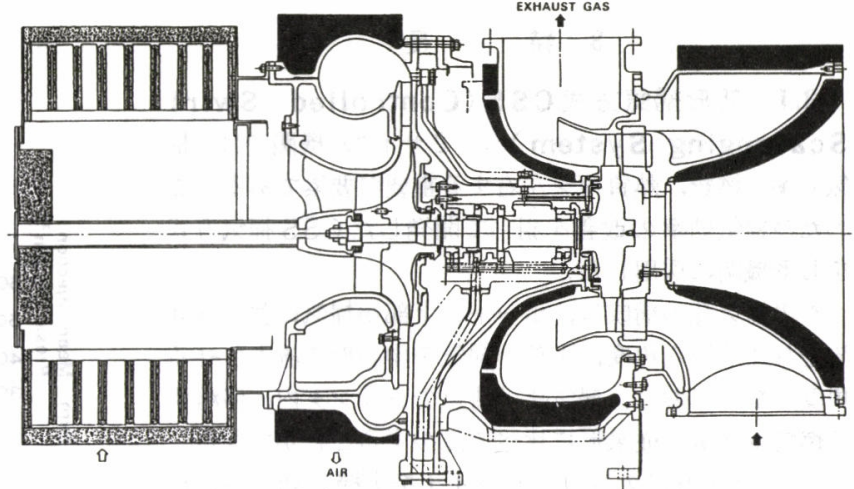

図 7 MET-SB形過給機断面図

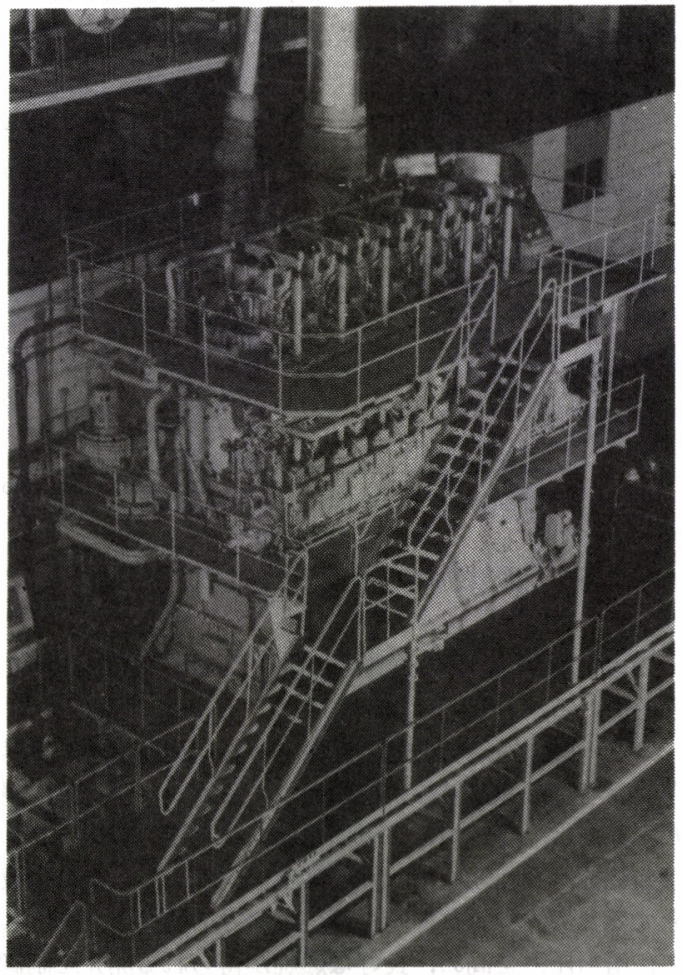

図 86 UEC 52 L 形機関

図 6 に, 52 L 形機関の外形図を示す. L形では, 過給 機への接近性, 作業性を考慮して, 容量の許す限り 1 台 の過給機としている．過給機は, UE 機関で従来から採 用している無冷却式MET-SB形を搭載している. 図7 に，その断面図を示す.

過給機配置については, 主機関と発電機関の間のスペ ースを節減でき, 機関室長さを数フレーム短縮できるこ と, 及び排気導管の配置が容易になるよう出力軸端側の 図6 の位置を選んだ.

空気冷却器についても, 船外取出し, 掃除等を考慮し て，上段の図の位置に配置した。

図8に, 6UEC 52L形機関初号機の写真を示す. 


\section{3. 特 長}

\section{1 新形掃気方式CSS (Controlled Swirl} Scavenging System) 2サイクル機関では,掃 気効率が燃費，熱負荷を左右する重要な要素である．こ のたび掃気効率の改善を狙って開発した CSS 掃気方式 をL形機関に採用した.

この掃気孔の構成は, ポートの上部が掃気に強い旋回 流を与える流入角度, 下部が掃気を中心部に流入させる 角度になっており, 掃気終了時点でシリンダ内に停滞す る燃焼ガス量を従来形に比へて減少するてとができた。

このCSS方式のシリンダライナを実機に組込み, 掃 気効率向上試験を事前に実施した。乙の結果を, 図 9 に 示す. CSS 方式により掃気効率を, 従来形に比し, 5〜 7\%向上させるととができた.

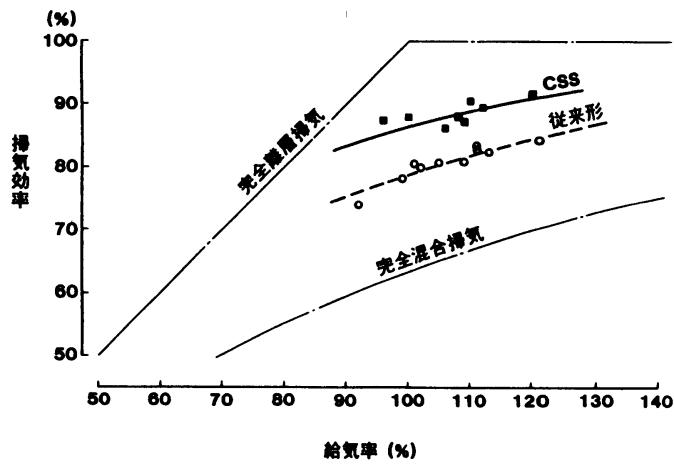

図 9 掃気効率の計測結果 (6UEC 45HA)

この手段が，L形の燃費低减量のうちの約 $2 \mathrm{~g} / \mathrm{ps} \cdot \mathrm{h}$ を 占めている.

3.2 開弁王制御式燃料弁 船舶運航形態の多様 化により，減速運航の例が増えている. ジャーク式燃料 噴射系では，必然的に，低回転域で噴射圧力が低下し， 噴䔉生成が高回転域に比べて劣る傾向にある. てれを改 善するため, 中低負荷時には, 燃料弁の開弁圧を高くし て, 噴射圧力を高め, 良好な燃焼が得られる開弁圧制御 式燃料弁を開発した。

$52 \mathrm{~L}$ 形で開弁圧を $320 \mathrm{~kg} / \mathrm{cm}^{2}$ と $550 \mathrm{~kg} / \mathrm{cm}^{2}$ にして 試験した結果を図 10 に示す. 開弁圧を高めると, 噴射 圧が増大し，噴射期間も短縮されて，かつその差は低負 荷程大きくなっている，その結果, 特に低負荷域での燃 費が改善された。これら燃焼改善は，受熱率の解析によ っても裏付けられている。

燃料弁の構造を図 11 に示す．開弁圧の切替は，あら かじめ設定された負荷又は回転数に応じて自動的に行わ れる. 燃料弁頭部にある串形の管制ピストンに制御空気 を投入することで, 弁ばねをピストンのストローク分強 めて開弁圧を上昇させ，又空気を排出することで開弁圧 を下げる，開弁圧を高くすると，極低負荷で不整噴射を

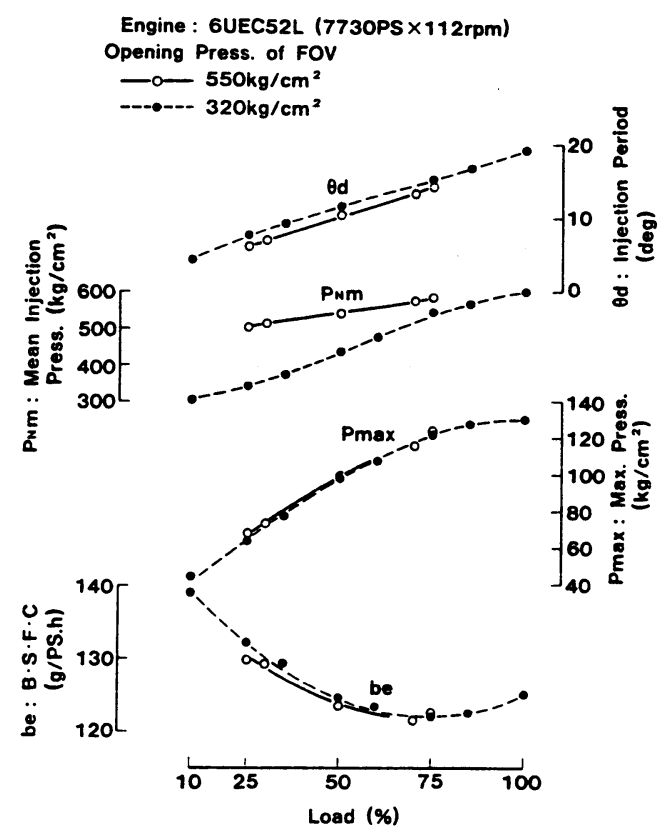

図 10 燃料弁開弁圧力変化性能比較

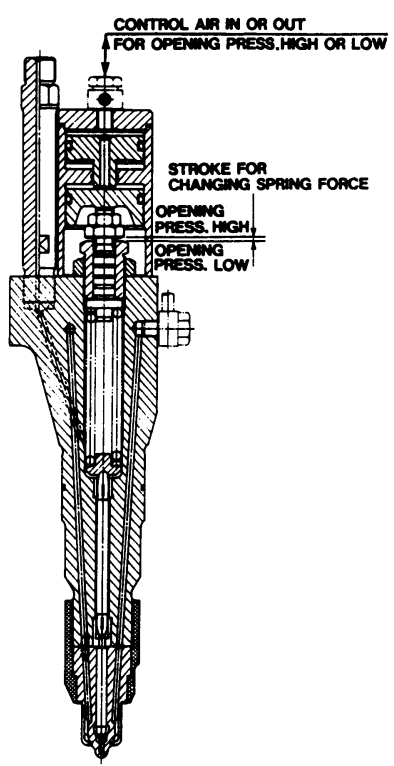

図 11 燃料弁構造

生じ，又高負荷域では噴射圧が過昇するので，高開弁圧 の運転範囲は，標準としては，30\%から 70 \%負荷まで としている.

3.3 補機の小容量化 UE機関の補機系統は,ジ ヤケット冷却水系 (燃料弁冷却水系を含む)之潤滑油系 (ピ ストン冷却, 過給機潤滑を含む)の各 1 系統より成り, 簡単な系統となっている．L形でもこの特長をそのまま 踏襲すると共に，諸試験の成果を反映させて補機容量を 
低減した. すなわち, 図 12 に示すように, 潤滑油・清 水の流量を $\mathrm{H}$ 形から各々 $27 \%, 60 \%$ 低減し, その結果, 補機所要動力を約 $45 \%$ 低减することができた．これによ って, 造船所における艤装費用や運航中の船内所要電力 の節減に寄与することができる。
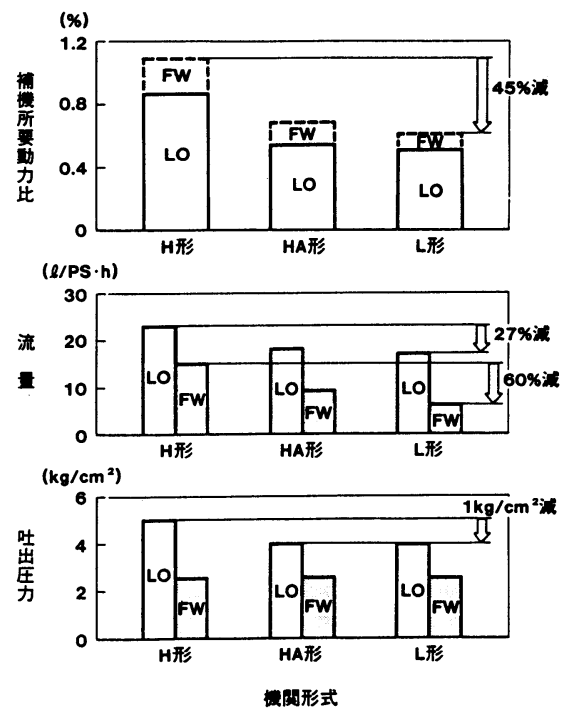

困 12 補機容量の低减

3.4 無冷却排気弁箱 UE機関では, 図7 に示 したように, 完全無冷却形三菱 MET-SB 形過給機を採 用しており, 過給機出口排気温度が比較的高く, 排熱回 収をより有効に行うことができる。

L形では, これに加えて, 排気弁箱内のガス通路部の 無冷却化を図り, 排気温度を約 5 C 上昇することができ た. 図 13 に, 従来形排気弁と比較して, その構造を示+ す. 排気弁の寿命に大きな影響を与える弁座部とブッシ 二部は従来どおり冷却をしているので, 排気弁の保守間 隔に悪影響を与えることはない，乙のことは，陸上運転 での排気弁各部の温度計測, 就航船での実船供与試験等

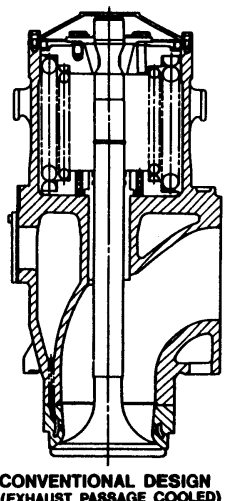

CONVENTIONAL DESIGN

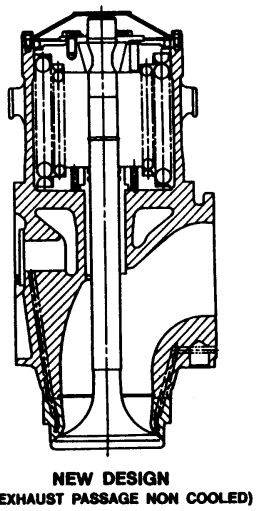

NEW DESICN
(EXHAUST PASSAGE MON COOLED)
で確認している

\section{4. 性能試験結果}

4.1 機関性能 UEC 52L 形初号機の出力 7730 $\mathrm{PS} / 112 \mathrm{rpm}$ における機関一般性能を図 14 に示す. 燃費 は，カタログ値より $2 \mathrm{~g} / \mathrm{ps} \cdot \mathrm{h}$ 以上低い值を目標としてい たが, $85 \%$ 負荷で $122.4 \mathrm{~g} / \mathrm{ps} \cdot \mathrm{h}, 100$ \%負荷で $125.0 \mathrm{~g} /$ $\mathrm{ps} \cdot \mathrm{h}$ 之，予想どおりの值を記録した。排気温度，掃気 圧力, 最高圧力等, その他の性能值も所期の計画值を達 成した。

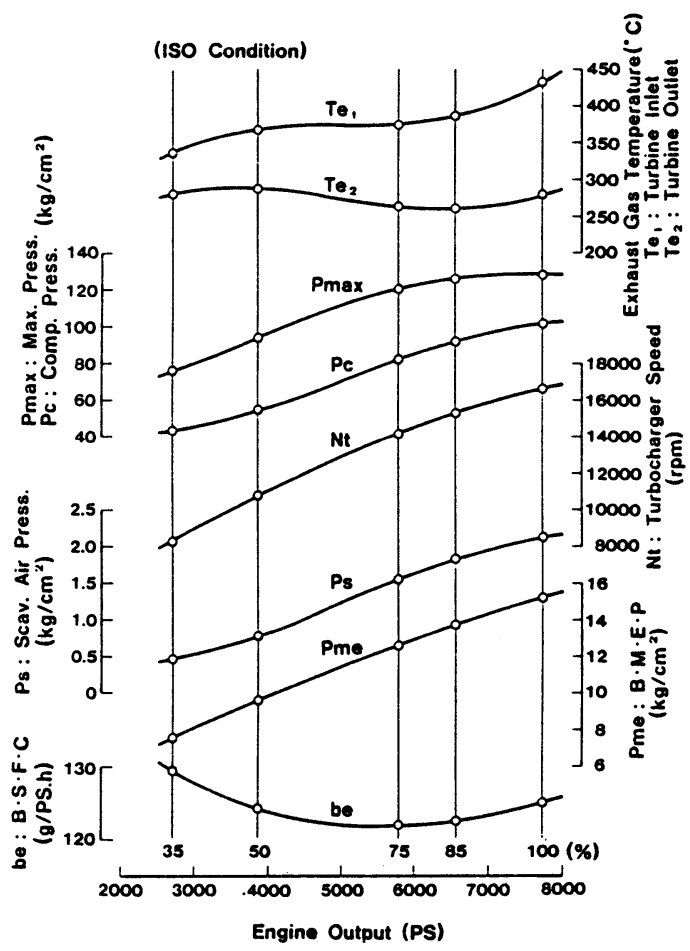

困 146 UEC 52 L 形機関性能曲線

UEC-HA形機関から採用しているMET-SB形過給 機については，軸受のまさつ損失を少くする等，更に低 負荷側の効率を改善した．との効率改善によって，L形 機関では, 後述のように, 低負荷性能が良好となってい る.

機関の運転状態 (出力と回転数の組合せ)は, 可変ピッ チプロペラの使用，あるいは，主機駆動発電機の採用等 により，可成り広い範囲に亘る場合がある，UE 機関で は, このような状況に対応して，許容する運転範囲を 広く設定しているが，乙の範囲内での機関性能を確認 すべく，定力率試験を実施した。この一般性能の結果 を図 15 に示す．従来機関之同様，燃費は常用負荷域で 最低で，かつ比較的フラットで好ましい特性となってい る.

図 13 排気弁構造比較 


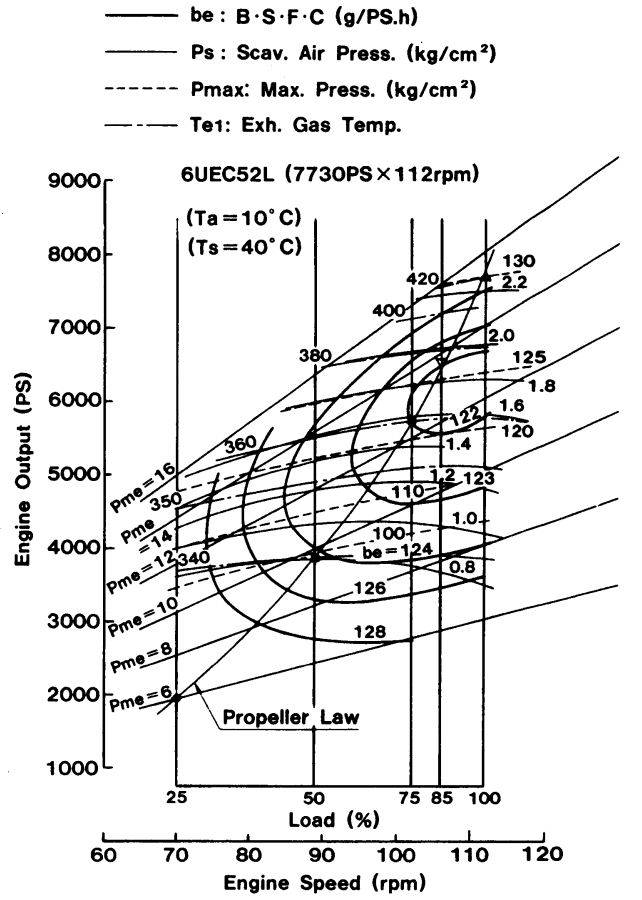

図 15 定力率性能曲線

\section{2 低予荷性能 UE機関では, H形の静圧過給} 機関以来, 補助ブロワを起動時より 50\%負荷域まで使用 することにしている．低負荷性能試験の目的は，前記の ように低負荷性能を改善したMET-SB形過給機を採用 しているL形機関において，どの負荷で補助ブロワを停 止して良いかを確認するために実施した。

その結果を, 初期の 6 UEC $52 \mathrm{HA}$ 形機関と比較して, 図 16 に示す．50\%負荷で比較してみると，HA形では 補助ブロワを停止すると, 排気温度や排気弁温度が上昇 したが，L形では停止してあほとんど上昇するてとなく， ほほ同一温度であった．L形は 50 \%以下の負荷域で, 補 助ブロワを停止しても掃気圧力や空気量の减り方も少く, これら温度の上昇傾向も少い，乙の性能差は，L形の掃 気圧力を若干高く設定したととや，MET-SB形過給機 の低負荷性能向上によるところが大きい.

従来の $\mathrm{H}, \mathrm{HA}$ 形では, 掃気圧力 $0.6 \mathrm{~kg} / \mathrm{cm}^{2}$ 程度 (MR 仕様で約 $50 \%$ 負荷に相当)まで補助ブロワを使用してい たが，L形では，掃気圧力 $0.5 \mathrm{~kg} / \mathrm{cm}^{2}$ (本機の計画出力 で約 40\%負荷に相当)にて, 従来形之同程度の性能を確 保できることがわかった．L形では, 補助ブロワの使用 範囲を 40\%負荷まで下げるととにした.

なお, 補助ブロワ 1 台が故障した場合を想定して, 補 助ブロワ 1 台のみ使用の試験も実施したが, 従来機関と 同様，始動も含めて何ら問題なく運転できるととを確認 した。

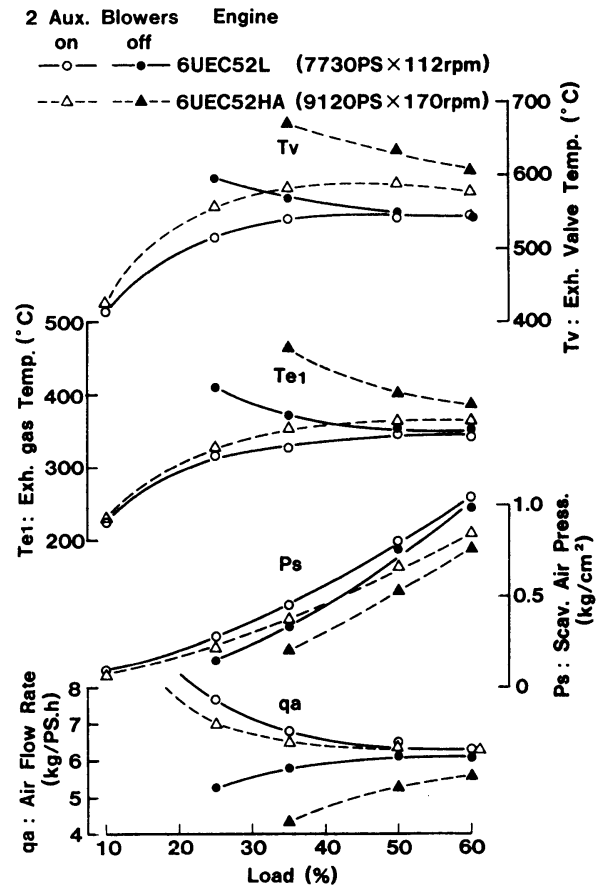

図 16 低負荷性能比較

4.3 過給機カット試驗過給機が万一故障した 場合を想定して，可能な上限出力を確認するために，過 給機カット試験を実施した。乙の結果を図 17 に示す。

試験は，過給機ローターを固定して，排気がタービン

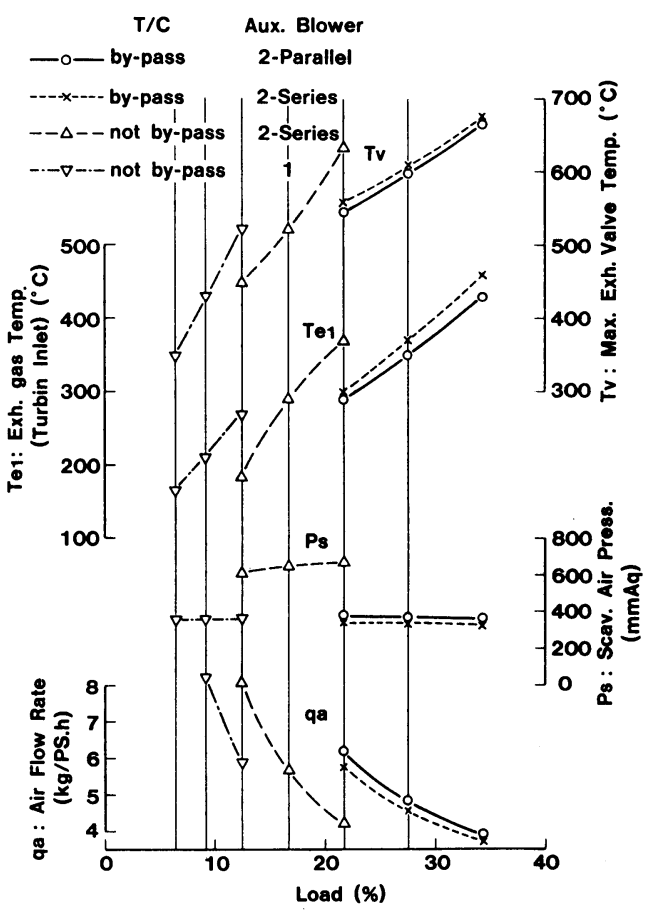

図 17 過給機カット運転性能比較 
を通過する場合と，過給機外部のバイパス管を通過する 場合，及び 2 台の補助ブロワを直列と並列に結合させる 場合, それに補助ブロワ 1 台のみの場合について行った。

図より，排気バイパスの有無については，排気温度や 排気弁の温度から，バイパスした方がより高い出力まで 出せる結果を得た。 バイパスした場合の, 補助ブロワの 結合方法については, 両者の差は小さく, 並列結合の方 が若干良い結果を得た.

本機関では, 上限出力の目安を, 就航後の経年変化も 考慮して, $60 \%$ 回転数比(約 $22 \%$ 負荷相当)に設定した が, 更に平均有効圧力の低い機関では, より高い回転数 比まで上げることができる.

\section{5. 信頼性確認試験結果}

5.1 燃焼室部品温度 燃焼室部品の温度計測結 果を, 各部品の主要点について, 図 18 亿示す.

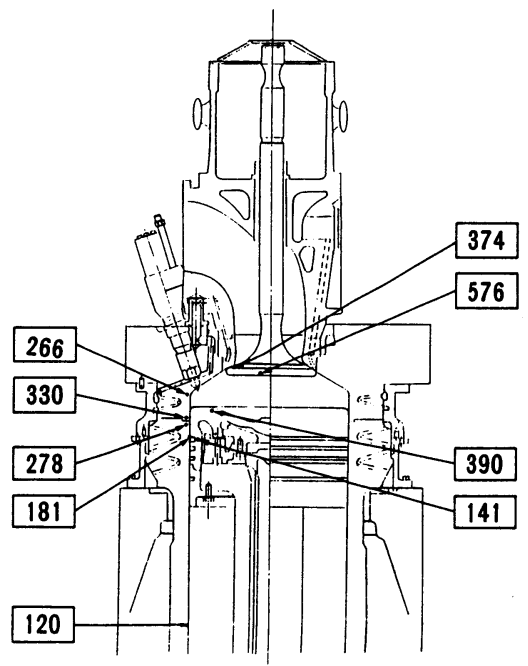

困 186 UEC 52 L 形機関燃焼室壁温度

ピストンクラウンの最高温度は $390^{\circ}$ Cで, 従来のリブ 式ピストンの温度より, 数十度低い結果を得た。

従来機関に比べると, 冷却油量を減らしているにあか かわらず, 冷却ノズルの合理的な配置により, 効果的に 冷却できていることが判った.

シリンダカバー, シリンダライナの最高温度は従来機 関とほぼ同レベルである.

リング・ライナの替動面温度は，潤滑性能及び酸食ま あうの点からみても, トップリングの上死点相当位置で 約 $180^{\circ}$ C と, 計画どおりの適正な結果を得た.

排気弁温度は, 弁金下面中央部で最高 $580^{\circ} \mathrm{C} て ゙$, 高温 ふ食に対してあ十分余裕のある温度である. シート部あ 最高約 370 C と, 従来形機関に比へ数十度も低い温度で あった。

又, 排気弁の円周方向温度差は, $10 \mathrm{C}$ 程度で非常に小
さく，均一とみなすととができる. 保守取扱いの点では, 燃料弁の数は少い方が良く, 排気弁温度や燃焼上から, $60 \mathrm{~L}$ 形であ 1 シリンダ 2 燃料弁で十分問題ないととを確 認した.

5.2 主要部応力 機関本体の応力計測結果を図 19 亿示す. 最高圧力の上昇, ロングストローク化, 小 連捍比に対して, FEM計算等で必要な剛性を確保する 本体構造としていたが，応力は従来形機関と同レベル又 は低目の結果で, 高い信頼性を有することを確認した。

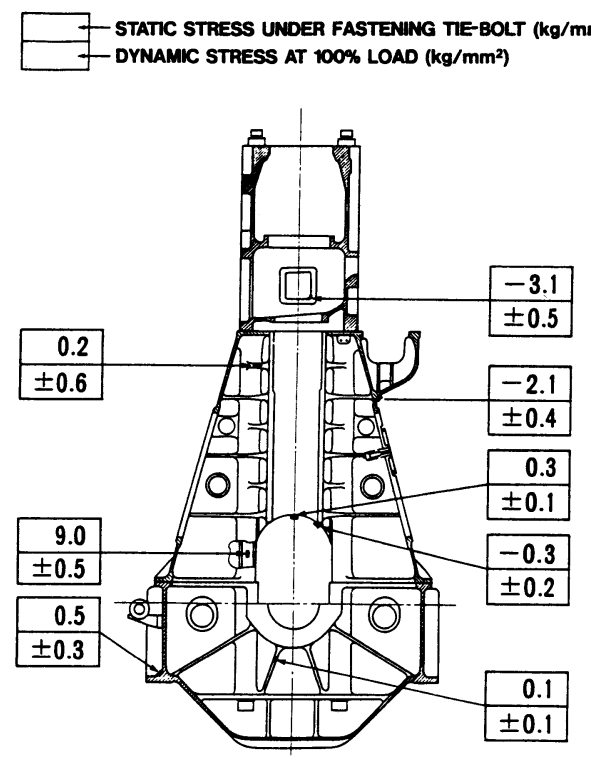

図 19 6UEC 52L 形機関本体応力

5.3 陸上据付時にハンンリングを動行っ て, 機関の固有振動数を計測した結果を図 20 亿示す. 又, ハンマリング実測結果を推定計算值と対比して, 表 2 に示す. 同表には, 参考のため, 実績のある 6 UEC 60 HA形についてあ併せて示した.

$6 \mathrm{UEC} 52 \mathrm{~L}$ 形の H形及び X 形の固有振動数計算值は, 機関主要寸法(高さ, 幅, 長さ)加, 従来形機関の実測 値をあとに推定計算した値である．6UEC 52 L形の実 測値は計算値より 15〜20\%高い結果を得た。乙れは機 関の剛性が従来機関より高かったてとを示している.

前後振動の固有振動数は， 2 次元モデルによる FEM 計算で推定した．乙の方法は，従来からかなりの精度 で推定できることがわかっており，6UEC 52 L形にお いてあ計算値は実測値と精度よく一致する結果を得た.

陸上運転時の機関振動の計測結果を図 21 亿示す. 機 関の H形共振点は $98 \mathrm{rpm}$ 付近に現われており，ハンマ リング試験における固有振動数と一致している. 共振時 のシリンダカバー左右方向の振幅は $0.16 \mathrm{~mm}$ と, ロン グストローク化されているにあかかわらず, 剛性が高い 機関本体のため小さく, 又, 全回転数域にわたり, 左右 

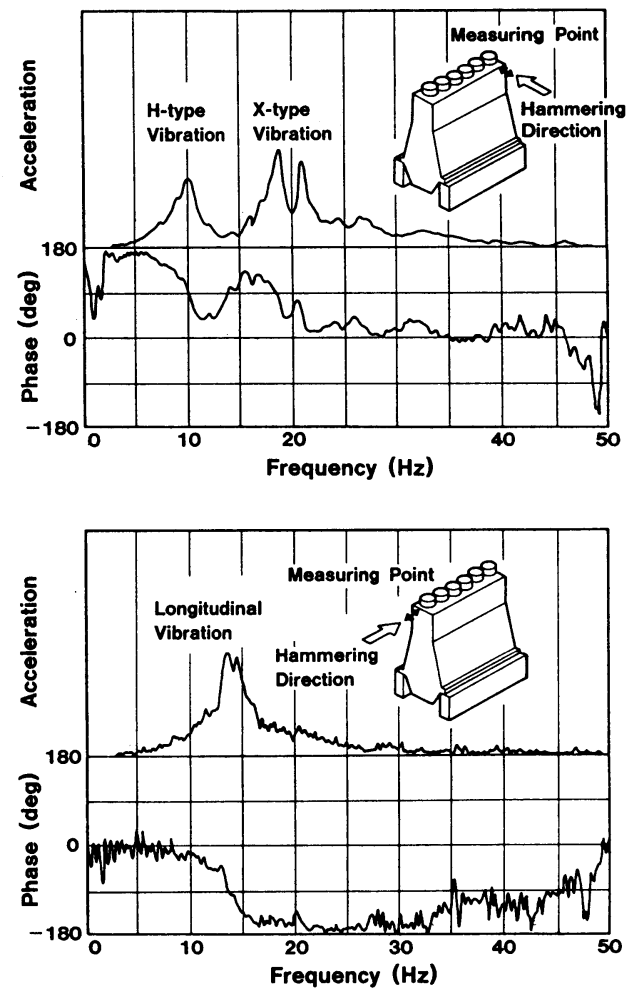

\begin{tabular}{|c|c|c|c|c|}
\hline \multirow{2}{*}{\multicolumn{3}{|c|}{ MR仕様時の機関回転数 $(\mathrm{rpm})$}} & 6UEC52L & GUEC6OHA \\
\hline & & & 133 & 140 \\
\hline \multicolumn{3}{|c|}{ ストローク/ボア $(\mathrm{cm})$} & $160 / 52(=3.08)$ & $150 / 60(=2.5)$ \\
\hline \multirow{9}{*}{$\begin{array}{l}\text { 固 } \\
\text { 有 } \\
\text { 振 } \\
\text { 数 }\end{array}$} & \multirow{3}{*}{$\begin{array}{l}\text { H } \\
\text { 形 } \\
\text { 振 } \\
\text { 到 }\end{array}$} & $\begin{array}{c}\text { 実測値 fmes } \\
(\mathrm{cpm} / \mathrm{Hz})\end{array}$ & $600 / 10.0$ & $492 / 8.2$ \\
\hline & & $\begin{array}{l}\text { 計算值 fcal } \\
(\mathrm{cpm} / \mathrm{Hz})\end{array}$ & $510 / 8.5$ & $480 / 8.0$ \\
\hline & & fmes/fcal & 1.18 & 1.03 \\
\hline & \multirow{3}{*}{$\begin{array}{l}\mathbf{x} \\
\text { 形 } \\
\text { 振 } \\
\text { 站 }\end{array}$} & $\begin{array}{c}\text { 実測值 fmes } \\
(\mathrm{cpm} / \mathrm{Hz})\end{array}$ & $1188 / 19.8$ & $888 / 14.8$ \\
\hline & & $\begin{array}{c}\text { 計算値 fcal } \\
\text { fmes/fcal }\end{array}$ & $1020 / 17.0$ & $840 / 14.0$ \\
\hline & & fmes/fcal & 1.16 & 1.06 \\
\hline & \multirow{3}{*}{$\begin{array}{l}\text { 前 } \\
\text { 後 } \\
\text { 振 } \\
\text { 趿 }\end{array}$} & $\begin{array}{c}\text { 実測值 fmes } \\
(\mathrm{cpm} / \mathrm{Hz})\end{array}$ & $846 / 14.1$ & 747125 \\
\hline & & $\begin{array}{l}\text { 計算値 fcal } \\
(\mathrm{cpm} / \mathrm{Hz})\end{array}$ & $848 / 14.1$ & $786 / 13.1$ \\
\hline & & fmes/fcal & 1.00 & 0.95 \\
\hline
\end{tabular}

表 2 実測固有振動数と計算推定値との比較

図 $206 \mathrm{UEC} 52 \mathrm{~L}$ 形機関ハンマリング試験結果

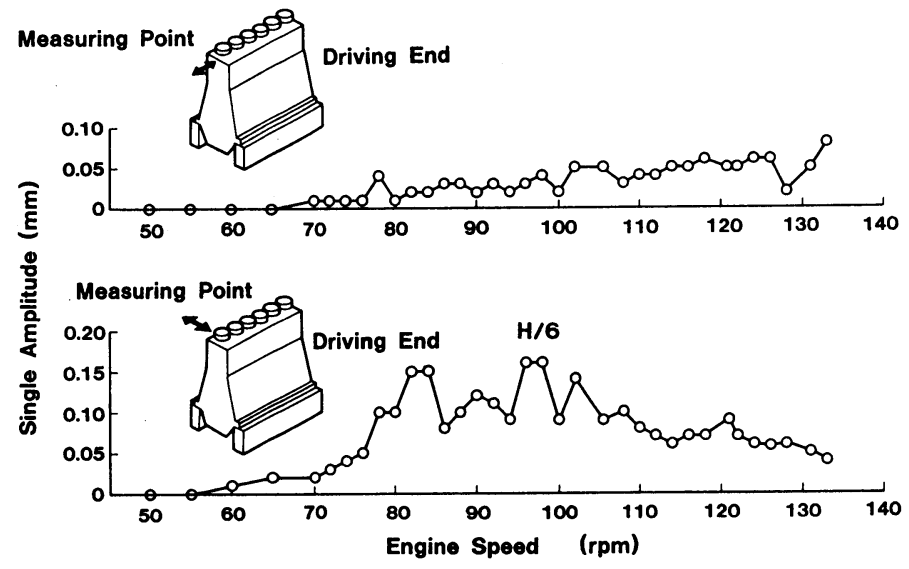

困 216 UEC 52 L 形機関振動計測結果

振動, 前後振動共, 振幅は十分小さい結果を得た.

\section{6. あとがき}

UEC - L 形機関の開発設計の思想, 主な特長と 6UEC $52 \mathrm{~L}$ 形機関初号機での主な試験結果について述べた.

L形機関は, H及ひ HA形機関の 300 台以上にのぼる
就航実績に加え, 新たに十分な基礎研究と実機試験, 長 期にわたる実船試験を行い，ユーザの立場に立って開発 と設計を行ってきた. そして, 初号機の諸試験結果から, L形で新たに導入した各特長は, 計画值を満足し, 十分 な性能と信頼性のあるととが確認できた。 